\begin{abstract}
The study investigated the effects of book piracy on publishing in Nigeria. Three research questions were formulated as thus: what are the causes of book piracy in Nigeria? What types of books are being pirated? What are the effects of book piracy on book business in Nigeria? Survey research method was used for this study. The population of this study is the entire branch managers of the publishing companies in Kano, Anambra and Lagos states. The population of the study is sixty three. Purposive sampling was used to select the three states as sample of the study. While considering the manageable number of the subjects of this study; the researcher used the whole population. Questionnaires were used to collect data for this study. The data collected were presented and analyzed using frequency distribution tables and percentages. The findings showed that: high cost of original books, get- rich-quick syndromes, and scarcity of original books as reasons for the growing piracy network in Nigeria. The findings also revealed that educational books, religious books, trade books, recreational books and reference books are the types of books being pirated. However, educational books are the most pirated books while recreational and reference books are least pirated books. The study discovered that book piracy affects investment in publishing business; discourage creativity among Nigerians; increase unemployment in publishing sector; lowers profitability to publishing companies and revenue generation to government. The research recommends among others that publishing companies should make books available to the people so as to prevent the pirates from using any opportunity resulted by lack of stock at the wake of high demand in the markets.
\end{abstract}

Keywords: book piracy, book business, publishing, Nigeria, copyright

\title{
Introduction
}

Book piracy is an offence that poses great threat to publishing as a business in Nigeria for education, government and the society at large. Bot-mang (2006) reveals that piracy destroys creativity, diminishes talents and denies the intellectuals of the rights to the benefits of their property. There have been increasing concerns from authors and publishing industry in Nigeria over illegal book trade. This is because, pirates do not bear origination of published materials yet they sell and profit from fake products in the markets depriving the publishers and authors of the Information Impact | Journal of Information and Knowledge Management 
benefits of their works. Adelekan (2011) posits that Piracy is an illegal and illegitimate reproduction of other people's works without their consent and those that engage in this business eat from the sweat of other people who must have invested their intellect, time and resources.

To publish a book, takes longer period, energies and a lot of processes from editing, designing, layout, illustration and proof- reading. After this rigorous endeavor the pirates produce exact copies and circulate them favorably in markets with genuine books, and have large profits by selling them significantly in lower price than the original publishers' products, which bear the cost of royalties to author and other over head cost. It is in this regard that Kolawole (2005) opines that pirates take major shares of the publishing industry in Nigeria.

The publishing companies in Nigeria cry out over the increase of the incidence of book piracy in Nigeria. It is in this regard that Adegbola (2004) maintains that " $40 \%$ to $50 \%$ of the publishing business has been taken over by the pirates as a result of the importation of pirated books from far East" This claim has been confirmed by many people in the publishing industry. Obidiegwu (2007) reveals that Longman lost \$1.5 to \$ 2 million, constituting 50\% of its potential yearly turnover to book piracy". This signifies that the activities of pirates have consistently led to the erosion of tremendous percentage of the total earnings of the industry. Invariably if allowed to flourish it will have serious effects on economic development as well as make the publishing industries to collapse.

Copyright was introduced and entrenched in the Nigeria's Copyright Act; one of the most salutary provisions of the Act is the conferment of the body with the responsibility of enforcing copyright laws. The Nigerian Copyright Commission was established to shoulder the responsibility of protecting all matters related to copyright in the country. The law gives protection to copyright owners with stiff penalties in the event of violation, yet publishers cry out over the increase in book piracy in the country despite the existence of the decree. The International Intellectual Property Alliance (2006), reports that piracy level in Nigeria is nearly $85 \%$ for all sections with estimate among the highest in the world. It is based on the aforementioned situations that this study is undertaken to investigate the matter.

Information Impact | Journal of Information and Knowledge Management 


\section{Effects of Book Piracy on Publishing in Nigeria}

\section{Research questions}

This study seeks to provide answers to the following research questions:

1. What are the causes of book piracy in Nigeria?

2. What types of books are pirated?

3. What are the effects of book piracy on book business in Nigeria?

The study covers three selected states in Nigeria. These are: Kano, Anambra and Lagos states. The study is limited to book piracy and all other forms of piracy are excluded from the study within the confines of Kano, Lagos and Anambra state. These states were selected to represent the respective regions in the country, namely; Northern, Western and Eastern regions, represented by Kano, Lagos and Anambra states respectively. This selection is based on the fact that the selected states are the centers of book trade in the country and also the breaking point of book piracy in Nigeria as Kolawole (2008) confirms that, major hotspots of book piracy in Nigeria are: Alaba, Onitsha, Ajegule and Kano state.

\section{Literature review}

Piracy is an act of reproducing movies, music, books or other copyrighted works without permission from the copyright owner. It is an illegal production or reproduction of the copyright works like phonograms, books, paintings, architectural drawings, films, broadcasts, computer software and many more for commercial purposes. Section 1 (1) of the Nigerian Copyright Act (1999), states that subject to this Section, the following shall be eligible for copyright: Literary works; Musical works; Artistic works Cinematography films; Sound recording; and Broadcasts. The section provides the different categories of works that the copyright law in Nigeria protects which include literary works such as books and other items of literary documents.

1. A literary, musical or artistic work is not eligible for copyright unless sufficient effort has been expended on making the work to give it an original character. To be original, the work must display at least a reasonable amount of creativity.

Information Impact | Journal of Information and Knowledge Management 
2. The work has been fixed in any definite medium of expression. The law considers a work to be fixed if it is recorded in some permanent format, like writing it down, storing it on a computer floppy disk or recording it on videotape.

However, in order to strike a balance between the society's need for access to knowledge and the need to rewards creativity, limited use of the copyright protected works are allowed without the authors consent. The limitations that are subject to certain statutory exemptions include carrying out a specified act for research purposes, private use, criticism or review and for use in prescribed educational institutions. The Nigerian Copyright Commission intensifies effort in enforcing the copyright law at various parts in order to control the menace of piracy. The report of the raids conducted across the country between July and September 2003 from the various copyright related offences reveals that over 230 suspected pirates were arrested. The breakdown of this indicates that 143 were arrested for suspected book piracy while 92 were arrested for piracy of musical work and are being prosecuted while over 70 copyright cases are pending at the various Federal High Courts across the country (Adewopo, 2006). Moreover, about 3000 copies of pirated textbooks worth over N3 million belonging to various publishers were confiscated (Yahuza, 2005).

The publishers publish different kind of books for the benefits of the society. The educational books are meant for educational purposes, such as nursery, primary, secondary and advanced level books, while religious books are publish for religious purposes and trade books are meant for the general readership. Book piracy is primarily dependent on two factors, namely, the price of the book and its popularity. These two factors positively contribute to piracy. Piracy generally is confined to both foreign and good indigenous books. The types of book mostly pirated are curriculum based as Obidiegwu (2007) states when displaying pirated books, the Longman's books found being pirated are new general mathematics, junior English project, Business Accounting, New Method English Dictionary, Brighter Grammar, Students Companions, Romeo and Juliet, Hamlet, Merchant of Venice, Commercial Typewriting, Pitman New Eva Short Hand, Animal Farm, Tales from Shakespeare, Additional Mathematics and Pitman Shorthand. Moreover, when displaying another pirated books, Adegbola (2008) states that the books Information Impact | Journal of Information and Knowledge Management 
included New School Physics for Senior Secondary Schools; New School Chemistry for SSS; New General Mathematics for SSS; Intensive English for SSS; and Nigerian Integrated Science Project, Pupils' Textbook 1

Aladesuyi (2008) notes that the problem of book piracy was first noticed as a consequence of the depreciation of the naira, which resulted in shrinking disposable income, Nigerians were forced to search for cheaper alternatives to different items, including books. In such circumstances, piracy provides escape route, because pirated books can be as cheap as possible. The basis of why book piracy exists had been amply illustrated by a number of studies undertaken in the past in various parts of the world including Nigeria. Ovieghara (1992) observes the following as the reason why book piracy persists in Nigeria:

a. The means of reproduction of graphic matter are easily available everywhere today as a result of technological advancements in the field of reprography over the last two decades.

The cost of the original book far exceeds the cost of reproduction.

b. Legal reproduction is generally either non-existent, lacks force of deterrence or is rendered ineffectually by the slow and expensive process of litigation.

c. The love of money or money or the get-rich quick syndrome which pushes its victims to strive to acquire wealth or material possession by every means

d. Piracy generally occurs when unauthorized reprints can improve on the Authorized version in terms of price or immediate availability.

e. A situation where demand far exceeds supply creates an incentive for the pirates to seek to fill the supply by producing fake copies.

The loss to copyright piracy alone, apart from other forms of infringement and sources of unpaid royalties due to copyright owners, is staggering. This amount represents lost investment in the economy, unpaid remuneration of right owners and the unrealized revenue that could have accrued to government for the development of the economy and the provision of necessary incentives to practitioners in the copyright industries.

Information Impact | Journal of Information and Knowledge Management 


\section{Methodology}

The survey research method was adopted for the study. The data collected are information about the views of publishers in the selected states.

Population of the study comprises all the branch managers of the publishing companies in Kano, Lagos and Anambra states as shown in table 1.

\section{Table 1: Number of publishers}

\begin{tabular}{|l|l|l|l|}
\hline S/N & State & No of Publishers & $\begin{array}{l}\text { No } \\
\text { subjects }\end{array}$ \\
\hline 1 & Lagos & 46 & 46 \\
\hline 2 & Anambr a & 10 & 10 \\
\hline 3 & Kano & 7 & 7 \\
\hline & Total & 63 & 63 \\
\hline
\end{tabular}

The instruments used for collecting data for this study is the questionnaire. The instrument was employed in order to ensure credibility of the research findings.

\section{Findings and discussions}

The data collected were presented and analyzed using descriptive statistics such as frequency distribution tables and simple percentages.

Information Impact | Journal of Information and Knowledge Management 
Table 2: Response rate

\begin{tabular}{|l|l|l|l|l|}
\hline S/N & States & $\begin{array}{l}\text { Distributed } \\
\text { Questionnaires }\end{array}$ & $\begin{array}{l}\text { Returned } \\
\text { questionnaires }\end{array}$ & $\%$ \\
\hline 1 & Lagos & 35 & 32 & 91.4 \\
\hline 2 & Anambra & 10 & 10 & 100 \\
\hline 3 & Kano & 6 & 6 & 100 \\
\hline Total & & 51 & 48 & 94.1 \\
\hline
\end{tabular}

The table revealed that Lagos state had the highest number of publishing companies, followed by Anambra state whereas Kano state appeared to have the least publishing companies.

Table 3: Causes of book piracy

\begin{tabular}{|l|l|l|l|l|l|l|l|}
\hline S/N & Causes of book piracy & A & \% & UD & \% & D & \% \\
\hline 1 & Poverty & 32 & 66.7 & 1 & 2.1 & 15 & 31.2 \\
\hline 2 & Scarcity of original books & 25 & 52.1 & - & - & 23 & 47.9 \\
\hline 3 & High cost of original books & 36 & 75 & 1 & 2.1 & 11 & 23 \\
\hline 4 & Ignorance of copyright law & 17 & 35.4 & 2 & 4.2 & 29 & 60 \\
\hline 5 & Get- rich-quick syndromes & 41 & 85.4 & 3 & 6.3 & 4 & 8.3 \\
\hline 6 & $\begin{array}{l}\text { Lack of confidence on legal } \\
\text { system }\end{array}$ & 21 & 43.8 & 15 & 31.3 & 12 & 25 \\
\hline
\end{tabular}

KEY: F=Frequency, $A=$ Agree, $U D=$ Undecided, $D=$ Disagree

Information Impact | Journal of Information and Knowledge Management 
The table indicated that $32(66.7 \%)$ respondents agree that poverty is the cause of book piracy. This revealed that poverty has significant role towards the activities of piracy in the selected states. Also, 25 (52.1\%) publishers and 19 (45.2\%) NCC respondents affirmed that scarcity of original books is a reason for book piracy. This finding corresponds with what Mahmood and Ilyas (nd) found in their research on Copyright and Book Piracy in Pakistan that unavailability of original copies was among the causes of book piracy. In addition, $36(75 \%)$ respondents agree that high cost of the original books is the cause of books piracy. The implication of this finding is that, if similar books are available in lower price, the buyers could buy the cheaper ones. It also tallies with the finding of Bankole (2010) on Piracy of some Copyrighted Information Resources among students of Olabisi Onabanjo University, when he discovered that the high cost of the original book was among the factors responsible for book piracy.

Table further revealed that $29(60 \%)$ publishers opined that ignorance of copyright law is not responsible for the activities of book piracy. This finding is agreement with the study of Nair (1999) on Copyright piracy in India, which revealed that most of the consumers of pirated books were fully aware that book piracy is an act of copyright violation. With regard to the get-richquick syndrome, $41(85.4 \%)$ publishers agreed that the main cause of book piracy is get-richquick. This finding support that of Ovieghare (1992) which state that get-rich-quick is what pushes others to book piracy. The implication of this is that publishers could not continue to invest heavily in publishing business where people freely pirated other people's works in order to get quick wealth.

Table 4: Types of pirated books

\begin{tabular}{|l|l|l|l|l|l|l|l|l|}
\hline $\begin{array}{l}\text { S/ } \\
\text { N }\end{array}$ & $\begin{array}{l}\text { Types of books } \\
\text { pirated }\end{array}$ & Much & \% & UD & \% & Few & $\%$ & Total \\
\hline 1 & Educational books & 48 & $\begin{array}{l}10 \\
0\end{array}$ & - & & - & - & 100 \\
\hline 2 & Religious books & 12 & 25 & 12 & 25 & 24 & 50 & 100 \\
\hline
\end{tabular}

Information Impact | Journal of Information and Knowledge Management 


\section{Effects of Book Piracy on Publishing in Nigeria}

\begin{tabular}{|l|l|l|l|l|l|l|l|l|}
\hline 3 & Trade books & 15 & $\begin{array}{l}31 . \\
3\end{array}$ & 9 & 18.8 & 24 & 50 & 100 \\
\hline 4 & $\begin{array}{l}\text { Recreational } \\
\text { books }\end{array}$ & 2 & 4.2 & 23 & 47.9 & 23 & 47.9 & 100 \\
\hline 5 & Reference books & 4 & 4.3 & 23 & 47.9 & 21 & 43.8 & 100 \\
\hline
\end{tabular}

As indicated in the table $48(100 \%)$ publishers agreed that educational books are the highest pirated books. The implication of this finding is that educational books are the most demanded books by the customers in the markets. Moreover, (23:47.9\%) respondents show that recreational books are not much pirated. Therefore, the finding shows that piracy on recreational books is very rare. The finding is quite expected because recreational books have less emphasis on the sight of Nigerians and for this reason the people do not pirate books that are not much demanded.

Table 5: Effects of book piracy on publishing companies

\begin{tabular}{|l|l|l|l|}
\hline S/N & Effects of book piracy & \multicolumn{2}{|l|}{ Publishers } \\
\cline { 3 - 4 } & & $\begin{array}{l}\text { Frequenc } \\
\mathbf{y}\end{array}$ & $\%$ \\
\hline 1 & Low investment & 41 & 33.1 \\
\hline 2 & Loss of in-come generation & 41 & 33.1 \\
\hline 3 & Discouraged re-investment & 42 & 33.8 \\
\hline 4 & No effects & - & - \\
\hline 5 & Others ( specify) & - & - \\
\hline
\end{tabular}

Information Impact | Journal of Information and Knowledge Management 
Effects of Book Piracy on Publishing in Nigeria

\begin{tabular}{|l|l|l|l|}
\hline & Total & 124 & 100 \\
\hline
\end{tabular}

The table shows that $41(33.1 \%)$ publishers indicated that book piracy affect the investment of book business, while regarding the loss of income generation the table further reveals that 41(33.1\%) publishers indicated that book piracy affect income generation of publishing industry. It is clear from the table that majority of the respondents affirmed the fact that book piracy seriously discourages their bid to invest in the publishing endeavor, as it retards their yearly turnovers and by extension profitability. The implication of this finding is that publishing companies may collapse since substantial among of their yearly turnovers is harmed. The response tallies with the finding by Nair (1999) that piracy of literary works leads to loss of revenue to publishers, authors and the national treasury.

\section{Major findings}

From the data that were analyzed and discussed on the research questions the following findings emerged:

1. That high cost of original books, get-rich-quick syndromes and scarcity of original books are the reasons for book piracy in the states studied.

2. That educational books, religious books, trade books, recreational books and reference books are the types of books being pirated. However, educational books are the most pirated books while recreational and reference books are least pirated books.

5.That book piracy affects investment in publishing business; discourage creativity among Nigerians; increased unemployment in publishing sector; lowers income generation to publishing companies, as it retards their yearly turnovers and by extension profitability and denies revenue generation to the government

\section{Conclusion}

Information Impact | Journal of Information and Knowledge Management 
Based on the findings of the study, it was apparent that book piracy seriously affects the development of publishing business in Nigeria. Thus, the adoption of the underneath recommendations proffered in this study will help to a great extent in enhancing the fight against book piracy.

\section{Recommendations}

In the light of the finding of this study and the conclusion reached, the following recommendations were made:

1. The Federal government should reduce duty on book materials and also provide free interest loan to publishing companies, this will lead to reduction of the cost of production and also it will force down the prices of original books. Publishers should make books available to the people so as to prevent the pirates from using any opportunity resulted by lack of stock at the wake of high demand in the markets. This can be achieve through synergy among publishers especially those that the distribution capacity of their books could not cover the entire country, so that their books could be found everywhere in Nigerian markets in times of demand. In the agreement, the publishers could sell their copyright to another publisher in another geographical area for a fixed time, during which the publisher would guarantee the availability of the book to the public in their domains, after that period the copyright would revert to the publisher, who could dispose of this right again.

2. To prevent pirates from the activities of pirating books, publishers should use security features in the process of producing their books such as eu mark, glitch pattern, watermark papers and micro text that will prevent the pirates from duplicating their books. These security features help to protect books from piracy by providing an image which will alert the buyer that the book is a pirated copy. Whatever attempt made to pirate the book a written image-sign portraying that the book is pirated copy, scanned copy or stolen copy will appear depending upon what the publishers decided to use as an image-sign.

3. Finally, all those involved in the book chain such as Nigerian publishers Association, Association of Nigerian Authors, Nigerian Book Sellers Association, Association of Nigerian Printers, Nigerian Library Association, and federal government should work together in Information Impact | Journal of Information and Knowledge Management

\section{3}


protecting the books from piracy as the effects of book piracy extends to governments and the society in general.

\section{References}

Adegbola, G. (2004). Book Publishers want more Funding for NCC. Copyright Bulletin, 1 (1).

Adegbola, G. (2008). Publishers intercept N30m pirated books in Lagos. Nigerian News. Available at http//www.nigeriandailynews.com.

Adelekan, A. (2011).Effects of Piracy on Book Publishing in the Country. Available at http://www.effectsma.com .

Adewopo, A. (2006). Pirated Goods Worth over $\$ 250$ Million Impounded Nation-wide. Copyright Bulletin, 3 (6),

Asien, A. (2008). Survey of copyright piracy in Nigeria. Abuja: Nigerian Copyright Commission

Bankole A. (2010).Piracy of Some Copyrighted Information Materials Among Students of Olabisi Onabanjo University, Available at http:www.ajol.infor/index.php/ajol .

Bot-mang, M. (2006). First NCC-NDLEA Trained Copyright Inspectors passout.Copyright Bulletin. December Vol.3 (6)

Echebiri, A. O (1995). The growing menace of Book Piracy. The publisher vol. 3(2)

International Intellectual Property Alliance (2009). Special Report on Copyright Protection and Enforcement in Nigeria. Available at www.iipa.com.

International Intellectual Property Alliance (2006). Special Report on Copyright Protection and Enforcement in Nigeria. Available at www.iipa.com.

Kolawole, S. (2005). Nigerian Book Pirates have gone International. Available at http://www.allAfrica.ww/stories/20050608014.html?page=2-similar.

Kolawole, S. (2008). Pain of publishing. Available at

Information Impact | Journal of Information and Knowledge Management

\section{4}




\section{Effects of Book Piracy on Publishing in Nigeria}

http://painofpublishing.org/content/127

Kolawole, S. (2010).Nigeria: Customs Partners NPA Tackle Book Piracy. Available at www.allafrica.com/stories/2010007090364.html.

Mahmood,K. \& Ilyas, M.(nd). Copyright and Book Piracy in Pakistan. Available at http://bookpiracypakistan.

Nair, N. K.(1999) ((ed). Study on the Copyright in India. Available at http://www.copyrightsafetysystem.com/studypiracy.html.

Nigerian Copyright Act and subsidiary legislation (1999). Abuja: Copyright Consult,

Obidiegwu, D. (2007) Longman cries out over increase in book piracy. Available at http://financialnigeria.com/NEWS/corporation/updates-itemsdetail-aspx $?$ items $=115 \$$ corpid+.=LONGMAN

Ovieghare E. E. (1992).Essay on Copyright Law and Administration in Nigeria .Ibadan:Y_Books,

Yahuza, S. (2005). Book Piracy: Prima Facie Case Established Against Accused. Copyright Bulletin, 2 (4),

Ibrahim Ahmadu is a lecturer in the Department of Library and Information Science, North West University, Kano. He can be reached at iroahmad@yahoo.com, iahmadu3@gmail.com

Information Impact | Journal of Information and Knowledge Management

\section{5}

